\title{
Hyönteiskasvatuksen edistäminen Etelä-Pohjanmaalla (ENTOLAB) - kokemuksia ja tuloksia hankkeesta
}

\author{
Ilkka Latomäki ${ }^{1}$, Jarkko Niemi ${ }^{2}$, Sandra Mellberg ${ }^{3}$, Maija Karhapää ${ }^{2}$, Risto Lauhanen ${ }^{1}$ ja Gun \\ Wirtanen $^{1}$ \\ ${ }^{1}$ SeAMK Ruoka, Seinäjoki \\ ${ }^{2}$ Luke, Seinäjoki ja Helsinki \\ ${ }^{3}$ Helsingin yliopisto Ruralia-instituutti, Seinäjoki
}

\section{TIIVISTELMÄ}

Hankkeen tavoitteena oli auttaa hyönteiskasvatukseen perustuvan yritystoiminnan käynnistymistä ja kehittymistä Etelä-Pohjanmaalla. Hanke toteutettiin ajanjaksolla 1.1.2016-31.3.2019. Hankkeen tavoitteena oli tuottaa tietotaitoa, joka auttaa hyönteisalan tuotannon aloittamista Etelä-Pohjanmaalla. Hanke koostui viidestä osiosta:

1. Tuotannonhallinta osion tarkoituksena oli arvioida tuotannon taloudellisuutta ja tunnistaa hyviä tuotantotapoja hyönteiskasvatuksen toteuttamiselle Suomessa. Osion tarkoituksena oli kartoittaa hyönteisten tuotantoprosessin kriittiset tekijät ja tekniset mahdollisuudet.

2. Eri ravintolähteiden soveltuvuus kotisirkkatuotannossa -osion tavoitteena oli selvittää varteenotettavien ravintolähteiden soveltuvuutta kotisirkkojen kasvatuskokeella. Kotisirkat oli valittu selvityksen kohteeksi, koska niiden kasvatusta harjoitetaan jo Etelä-Pohjanmaalla.

3. Tuote- ja tuotantoturvallisuuden varmistaminen -osiossa tavoitteena oli laatia tuottajien käyttöön ohjeistus, joka sisältää käytännönläheisiä ohjeita tuotannon riskien hallitsemiseksi.

4. Tuotteiden käyttöarvo ja saattaminen markkinoille -osion tavoitteena oli selvittää hyönteisten käyttöarvoa elintarvikkeena ja rehuna. Lisäksi järjestettiin asiantuntija- ja sidosryhmätyöpajoja, joissa kehitettiin keinoja tuoda hyönteisiä ruokapöytiin.

5. Tulosten jalkauttaminen -osion tavoitteena oli viestiä hankkeen tuloksia niiden hyödyntäjille erilaisten tiedotus- ja viestintäkeinojen avulla. Loppuseminaarissa käsittelimme hyönteisten käyttöä eri näkökulmista.

Hankkeessa tehtyjen ruokintakokeilujen avulla, voidaan todeta, että kotisirkkojen kasvatus tapahtuu tuoteturvallisuuden kannalta haastavissa olosuhteissa ja että kotisirkkojen rehuja on suunniteltava hyönteislajin ravintovaatimukset ja rehulainsäädäntö huomioiden. Ruokintakokeilussa käytettyjen rehujen raaka-aineet kerättiin Etelä-Pohjanmaan alueelta. Rehut pyrittiin myös valmistamaan siten, että yksittäisellä kasvattajalla olisi mahdollisuus rehunvalmistukseen tilallaan. Ruokintakokeilun tuloksena voidaan todeta, että hyönteisten ruokinnan suunnittelu vaatii enemmän tietoa ja tutkimusta kasvatuksen optimoinnin tueksi. Hankkeen aikana järjestetyissä työpajoissa todettiin, että automatisointi on suuren mittakaavan tuotannon kriittinen menestystekijä. Hankkeen tuotoksina syntyi kaksi opasta, joista ensimmäinen keskittyy hygieenisten kasvatustilojen suunnitteluun ja toinen hyönteisten yleisemmin hyönteisten kasvattamiseen elintarvikkeeksi. Hygieniaoppaasta löytyy kiinnostuneille viljelijöille ohjeita, miten pystytään luomaan hygieeniset sirkkojen kasvatustilat. (Taustalla European Hygienic Engineering \& Design Groupin (EHEDG) ohje 44 "Hygienic Design Principles for Food Factories"). Kasvatusoppaassa keskitytään kotisirkkojen kasvatukseen, prosessointiin ja elintarvikekäyttöön. Lisäksi käsitellään mm. jauhomatojen ja mustasotilaskärpästen kasvatusta ja taloudellisia tunnuslukuja.

Asiasanat: hygieeniset kasvatustilat, hyönteiskasvatus, ruokaketju, ruokaturvallisuus

\section{Johdanto}

ENTOLAB-hankkeen, joka toteutettiin syksystä 2016 kevääseen 2019, tavoitteena oli auttaa hyönteiskasvatukseen perustuvan yritystoiminnan käynnistymistä ja kehittymistä Etelä-Pohjanmaalla, selvittää keinoja kannattavaan ja lainsäädännön mukaiseen kotisirkkatuotantoon, sekä selvittää sivuvirtojen hyödyntämismahdollisuuksia. Hanke koostui seuraavista viidestä osiosta: 
1) Tuotannonhallinnassa tarkoituksena oli arvioida tuotannon taloudellisuutta ja tunnistaa hyviä tuotantotapoja hyönteiskasvatuksen toteuttamiselle Suomessa. Osion tarkoituksena oli kartoittaa hyönteisten tuotantoprosessin kriittiset tekijät ja tekniset mahdollisuudet.

2) Eri ravintolähteiden soveltuvuus kotisirkkatuotannossa -osion tavoitteena oli selvittää varteenotettavien ravintolähteiden soveltuvuutta kotisirkkojen kasvatuskokeella. Kotisirkat oli valittu selvityksen kohteeksi, koska niiden kasvatusta harjoitettiin Etelä-Pohjanmaalla.

3) Tuote- ja tuotantoturvallisuuden varmistaminen -osiossa tavoitteena oli laatia tuottajien käyttöön ohjeistus, joka sisältää käytännönläheisiä ohjeita tuotannon riskien hallitsemiseksi.

4) Tuotteiden käyttöarvo ja saattaminen markkinoille -osion tavoitteena oli selvittää hyönteisten käyttöarvoa sekä elintarvikkeena, sillä MMM muutti syyskuussa 2017 EY-asetuksen uuselintarvikkeista siten, että tuotteita kokonaisista hyönteisistä saa olla kaupan, että rehuna. Järjestimme myös asiantuntija- ja sidosryhmätyöpajoja, joissa kehitettiin keinoja tuoda hyönteisiä ruokapöytiin.

5) Tulosten jalkauttaminen -osion tavoitteena oli viestiä hankkeen tuloksia niiden hyödyntäjille erilaisten tiedotus- ja viestintäkeinojen avulla. Loppuseminaarissa käsittelimme hyönteisten käyttöä eri näkökulmista.

\section{Nostoja hankkeen tuloksista}

Hankkeen tuotoksina syntyi kaksi opasta. "Clean and easy cricket rearing - A guide on hygienic building design in rearing facilities" -opas keskittyy kotisirkkojen hygieenisten kasvatustilojen suunnitteluun ja "Hyönteiskasvatuksen edistämiseen liittyvät tekijät" -opas hyönteisten kasvattamiseen elintarvikkeeksi. Ensimmäisenä mainitusta oppaasta löytyy kiinnostuneille viljelijöille ohjeita, miten pystytään luomaan hygieeniset sirkkojen kasvatustilat. Kasvatusoppaassa keskitytään kotisirkkojen lisäksi jauhomatojen ja mustasotilaskärpästen kasvatukseen sekä kotisirkkakasvatuksen taloudellisiin tunnuslukuihin ja prosessointiin elintarvikkeena. Näistä kahdesta oppaasta löytyy kattavammat tiedot hankeen töistä.

\section{Hyönteiskasvattamon tuotantohygienia}

Tämä osio keskittyi sirkkojen hygieeniseen kasvattamiseen sisältäen huomiotavat suuntaviivat tilojen, prosessien ja laitteiden hygieenisessä suunnittelussa. Hyönteiset uutena elintarvikeryhmänä aiheuttaa haasteita, kun tutkimusta tuoteryhmästä on rajallisesti ja kaikkia riskejä ei tunneta. Toimijan vastuulla on huolehtia hyönteisten hygieenisestä elintarviketuotannosta, ehkäistä tautien leviäminen, sekä ilmoittaa mahdollisesta tartuntatautiepäilystä, jos tällainen havaitaan (Evira 2018b). Osio tarjoaa ohjeita viljelijöille, jotka haluaisivat perustaa pienen mittakaavan sirkkaviljelmän. On kiinnitettävä huomiota hyvään hygieeniseen suunnitteluun ja rakentamiseen, tarkoituksenmukaiseen rakennuksen sijaintiin ja asianmukaiseen tilojen järjestämiseen. Tämä on välttämätöntä, jotta riskejä voidaan hallita tehokkaasti. Hyönteiskasvatushan luokitellaan alkutuotannoksi, joten osio perustuukin yleisiin ohjeisiin elintarvikkeiden hygieeniseen tuottamiseen. Pakastettujen, ei-jälkikäsiteltyjen hyönteisten kuljetus, käsittely ja varastointi katsotaan osaksi alkutuotantoa niin kauan, kuin tuotteiden luonne ei muutu (Evira 2018a). Kuvassa 1 on eroteltu alkutuotannon tuotantovaiheet ruoan prosessoinnista (Dobermann ym. 2017): 


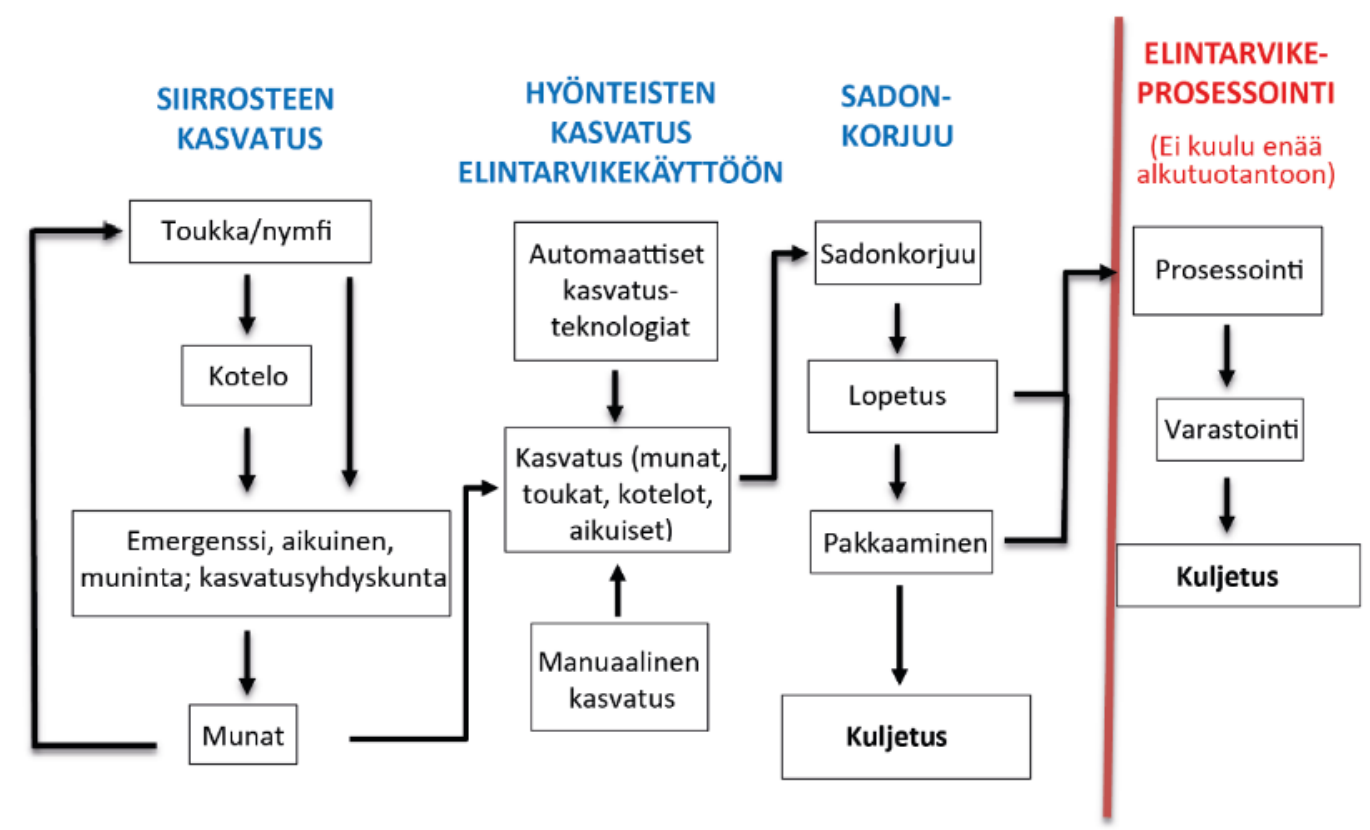

Kuva 1. Alkutuotantoon liittyvät tuotantovaiheet hyönteiskasvatuksessa näkyvät sinisenä. Punaisena merkityt vaiheet lasketaan ruoan prosessoinniksi (Dobermann ym. 2017).

Yleinen tapa perustaa viljelypaikka on olemassa olevassa rakennuksessa, esim. tyhjään jäänyt sikala tai siirrettävä kontti. Rakennusten lattiat tulisivat olla ympäröivää maanpintaa korkeammalla tasolla, jotta sade- tai tulvavesi ei kerry rakennukseen. Laitteistojen ja muiden huoltoon liittyvien rakennelmien yläpuolella, alapuolella ja ympärillä pitää olla riittävästi tilaa vaivattomaan siivoukseen ja kunnossapitoon. Henkilöstö- ja materiaalivirrat on suunniteltava siten, että ristikkäinen kontaminaatio voidaan minimoida (Kuva 2). Kokeilun aikana otettujen pintahygienianäytteiden avulla voitiin kartoittaa kasvattamon hygieenisiä riskejä. Tuotantolaitoksen rakennukset, tilat, laitteet ja välineet tulee sijoittaa, suunnitella ja rakentaa siten, että (EHDG 2014):

- toteutus mahdollistaa asianmukaisen kunnossapidon, puhdistuksen ja desinfioinnin,

- pinnat ja materiaalit, erityisesti elintarvikekosketuspinnat, ovat myrkyttömiä, käyttötarkoitukseen soveltuvia, sekä riittävän kestäviä ja helppoja pitää puhtaana ja kunnossa,

- kontaminaatio (pinnat, raaka-aineet, hyödykkeet, ilma, vesi yms.) on minimoitavissa,

- lämpötila, ilmankosteus ym. ovat säädettävissä tarkoituksenmukaisesti ja

- kasvatustilat ovat tehokkaasti suojattuja tuhoeläinten sekä sisäänpääsystä että pesimisestä. 


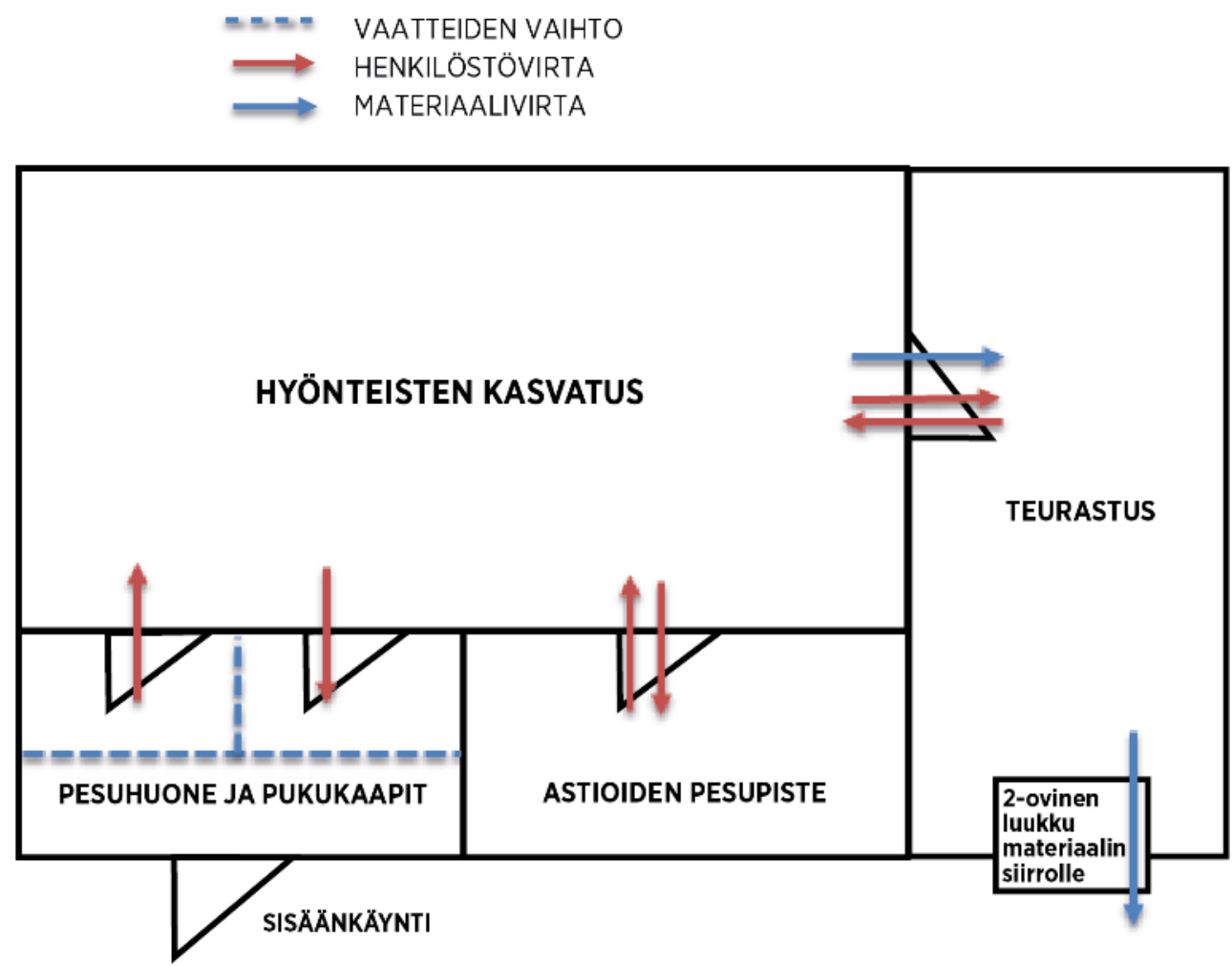

Kuva 2. Henkilöstö- ja materiaalivirrat pitää huomioida sirkkakasvattamossa

\section{Olosuhdeselvitys ja ruokinta}

Hyönteisten kasvatuksessa onnistuminen vaatii hyönteisten lajikohtaisen biologian, kasvatusolosuhteiden ja ravintoainetarpeiden tuntemista, jotta voidaan luoda optimaaliset olosuhteet hyönteisten kasvatukselle. Kasvatettavan hyönteislajin tulisi olla helposti kasvatettava, hyvän makuinen, houkuttelevan värinen ja lajin tulisin soveltua rehukäyttöön ja ruuaksi esim. kotisirkka (Acheta domesticus). Kotisirkan (Kuva 3) elinkaaren voi jakaa kolmeen päävaiheeseen, joita ovat muna, nymfi ja aikuinen. Toukka-asteet (nymfit) ovat aikuisen näköisiä, mutta pienempiä (Cloutier 2015). Koko elinkaareen kuluu noin 2-3 kuukautta (kasvulämpötila $26-32{ }^{\circ} \mathrm{C}$ ).

Kasvatettavan hyönteislajin olisi hyvä olla paikallinen laji, että sen kasvatuksesta ei aiheudu vaaraa ympäristölle. Hyönteislajin pitäisi tulla toimeen paikallisissa ilmasto-olosuhteissa, jotta kasvatustilan lämmitys- ja valaistuskustannukset eivät aiheuta suuria ylimääräisiä kuluja. Massatuotantoon tarkoitetulla hyönteislajilla tulisi olla nopea kasvu ja kehityskierto, vähäinen kuolleisuus ja hyvä lisääntymiskapasiteetti (van Huis ym. 2013). Potentiaalisella kasvatukseen soveltuvalla hyönteislajilla on myös hyvä rehuhyötysuhde, luontaisesti pieni tilantarve ja hyvä tautien vastuskyky. Tällaisia hyviä massatuotantoon soveltuvia lajeja ovat mm. mustasotilaskärpänen (Hermetia illuscens) rehuksi ja jauhopukki (Tenebrio molitor) sekä ruuaksi että rehuksi. Hyönteistuotantoa suunnitellessa on myös hyvä pohtia, että mikä on hyönteistuotannon ekologinen jalanjälki esim. kasvatettavan hyönteislajin kasvihuonekaasupäästöjen määrä tai vedentarve. Kasvatuslaatikossa rehu, vesilähde ja tuoreruoka tarjoillaan matalilta lautasilta tai tarjottimilta, jotka sijoitetaan kyljellään olevien munakennostojen tai muiden kalusteiden päälle. Tutkimusten mukaan optimaalisessa kotisirkkojen rehussa on 20-30\% proteiinia, 32-47 \% hiilihydraatteja ja 3.2-5.2 \% rasvoja. "Hyönteiskasvatuksen edistämiseen liittyvät tekijät" -oppaassa on tarkemmat tiedot kotisirkkojen vitamiini-, kivennäis- ja hivenainetarpeista. 


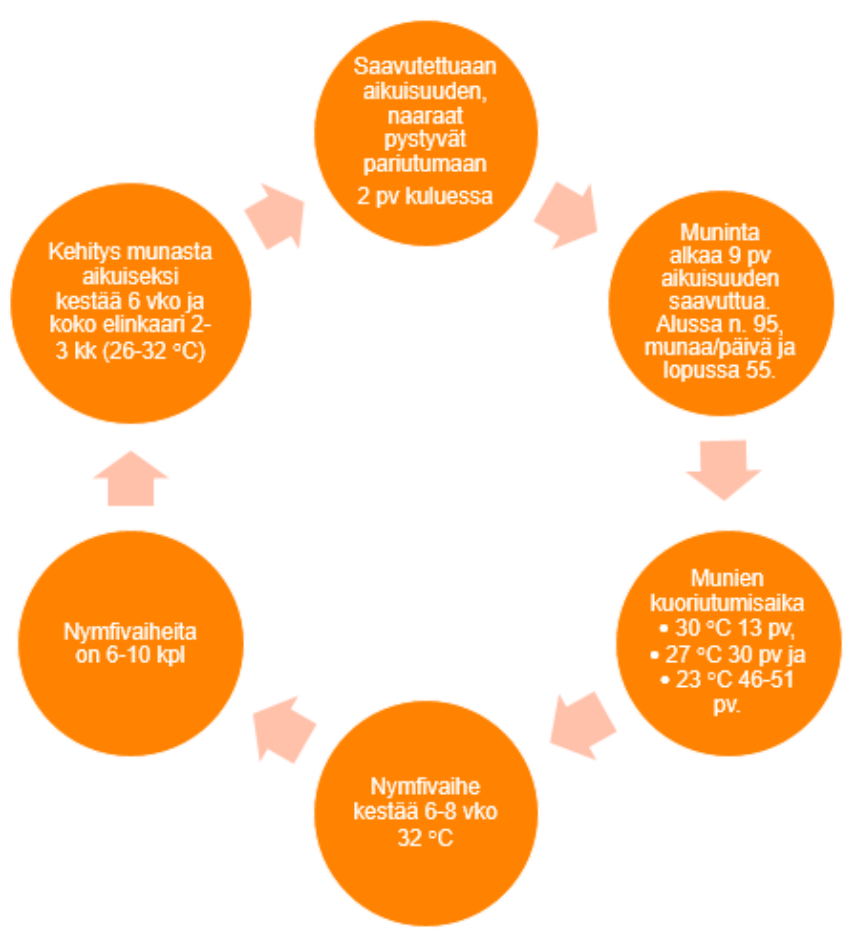

Kuva 3. Kotisirkan elinkaari

\section{Kasvatuskokeet}

Kasvatuskokeilulla saatiin arvokasta tietoa hyönteisten kasvattamisesta käytännössä ja kotisirkkojen ravinnosta. Kokeilu osoitti, etteivät kotisirkat hyväksy ravinnokseen mitä tahansa rehua, vaan niiden rehun tulee olla suunniteltu vastaamaan kotisirkkojen ravintovaatimuksia. Hyönteisruoan ravitsemuksellisuus johtuu lajista, syötetystä rehusta, kasvuajasta, kasvuolosuhteista ja hyönteisiin kohdistetuista prosessointimenetelmistä. Tästä aiheesta enemmän "Hyönteiskasvatuksen edistämiseen liittyvät tekijät” -oppaassamme.

\section{Yhteenveto}

Hankkeessa tehtyjen ruokintakokeilujen perusteella kotisirkkojen kasvatus tapahtuu tuoteturvallisuuden kannalta haastavissa olosuhteissa. Kotisirkkojen rehuja on suunniteltava hyönteislajin ravintovaatimukset ja rehulainsäädäntö huomioiden. Kokeilussa käytettyjen rehujen raaka-aineet kerättiin Etelä-Pohjanmaan alueelta ja rehut valmistettiin siten, että yksittäisellä kasvattajalla olisi mahdollisuus rehunvalmistukseen tilallaan. Kasvatuskokeilulla saatiin arvokasta tietoa hyönteisten kasvattamisesta käytännössä ja kotisirkkojen ravinnosta. Kokeilu osoitti, etteivät kotisirkat hyväksy ravinnokseen mitä tahansa rehua, vaan niiden rehun tulee olla suunniteltu vastaamaan kotisirkkojen ravintovaatimuksia. Ruokintakokeilun tuloksena voidaan todeta, että hyönteisten ruokinnan suunnittelu vaatii enemmän tietoa ja tutkimusta kasvatuksen optimoinnin tueksi. Lisäksi todettiin työpajoissa, että automatisointi on suuren mittakaavan tuotannon kriittinen menestystekijä. Virrat, esim. henkilökunta, rehu, jätteet ja hyönteiset, rakennuksissa on suunniteltava siten, että ristikkäinen kontaminaatio voidaan minimoida. Laitteistojen ja muiden huoltoon liittyvien rakennelmien yläpuolella, alapuolella ja ympärillä pitää olla riittävästi tilaa, jotta on mahdollista siivota ja ylläpitää tuotantoa. 


\section{Lähteet}

Cloutier, J. 2015. Edible insects in Africa: An introduction to finding, using and eating insects. Agrodok 54. Agromisa Foundation and CTA, Wageningen. 80 s. ISBN 978-90-8573-146-7. https:// hdl.handle.net/10568/73150.

European Hygienic Engineering \& Design Group (EHEDG) 2014. Hygienic Design Principles for Food Factories (DOC 44). EHEDG, Frankfurt. 133 s.

Evira 2018a. Frequently asked questions about insect food. Viitattu 6.6.2018. https://www.evira.fi/en/foodstuff/manufacture-and-sales/food-categories/insects-as-food/frequently-askedquestions.

Evira 2018b. Hyönteiset elintarvikkeena. Haettu 2.5.2018 https:/www.evira.fi/globalassets/tietoaevirasta/lomakkeet-ja-ohjeet2/elintarvikkeet/eviran_ohje_10588_2_fi.pdf.

Dobermann, D., Swift, J. \& Field, L. 2017. Opportunities and hurdles of edible insects for food and feed. Nutrition Bulletin 42: 293-308. https://doi.org/10.1111/nbu.12291

Ortiz, J.A.C., Ruiz, A.T., Morales-Ramos, J.A., Thomas, M., Rojas, M.G., Tomberlin, J.K., Yi, L., Han, R., Giroud, L. \& Jullien, R.L. 2016. Chapter 6 - Insect mass production technologies. Teoksessa: Dossey, A.T., Morales-Ramos, J.A. \& Rojas, M.G. (toim.) Insects as sustainable food ingredients. Academic Press, San Diego. s. 153-201. ISBN 9780128028568. https://doi.org/10.1016/B978-0-12-802856-8.00006-5

Patton, R.L. 1967. Oligidic diets for Acheta domesticus (Orthoptera: Gryllidae). Annals of the Entomological Society of America 60: 1238-1242. https://doi.org/10.1093/aesa/60.6.1238

van Huis, A., van Itterbeeck, J., Klunder, H., Mertens, E., Halloran, A., Muir, G. \& Vantomme, P. 2013. Edible insects: future prospects for food and feed security. FAO, Rome. E-ISBN 978-92-5-107596-8. $187 \mathrm{~s}$. 